\title{
BENTUK PEMBELAJARAN VOKAL SECARA DARING
}

\author{
Alfa Kristanto \\ Sekolah Tinggi Theologia Abdiel \\ alfaomega.kristanto@gmail.com
}

\begin{abstract}
Abstrak
Tahun 2020 terjadi sebuah peristiwa penting dalam sejarah dunia yaitu adanya pandemi virus Covid-19 yang berdampak pada dunia pendidikan secara umum dan bidang seni secara khususnya. Indonesia merupakan salah satu negara yang terdampak oleh virus tersebut. Beragam kebijakan pemerintah telah diambil sebagai upaya menghambat persebaran virus tersebut. Kebijakan pemerintah juga berdampak pada pengaturan sektor pendidikan di Indonesia. Terdapat perubahan proses pembelajaran yang semula dilakukan secara tatap muka di kelas kemudian karena adanya pandemi ini maka terdapat penyesuaian yaitu proses pembelajaran dilakukan secara daring. Munculnya inovasi dari para pengajar turut memberi warna dalam proses pembelajaran selama pandemi Covid-19. Proses pembelajaran di bidang seni terdapat penyesuaian pada teknis kegiatan belajar mengajar kepada peserta didik. Pemanfaatan ruang virtual menjadi prioritas utama di masa pandemi Covid-19 untuk keberlanjutan kegiatan belajar mengajar. Hal tersebut terjadi pada seni musik khususnya proses pembelajaran vokal yang dilakukan secara daring. Semula praktik vokal dilakukan melalui bertatap muka dalam satu ruangan secara luring maka sekarang hal tersebut mendapat penyesuaian yaitu pembelajaran praktik vokal dilakukan melalui virtual. Pembelajaran vokasl secara daring merupakan kegiatan belajar mengajar yang berkaitan dengan teknologi di dalam pelaksanaannya. Bentuk pembelajaran vokal secara daring dapat dilakukan dengan memanfaatkan beberapa aplikasi digital. Diantaranya menggunakan aplikasi WhatsApp dengan memanfaatkan fitur video call dan mengirim rekaman hasil latihan oleh peserta didik. Pemanfaatan fitur dari WhatsApp memiliki keunggulan masing-masing dan hal tersebut memberikan paradigma baru jika keduanya digunakan dalam proses pembelajaran praktik vokal secara daring.
\end{abstract}

Kata kunci: bentuk pembelajaran vokal secara daring; pendidikan seni; pembelajaran vokal

\begin{abstract}
The year 2020 saw an important event in world history, namely the Covid-19 virus pandemic which had an impact on the world of education in general and the arts in particular. Indonesia is one of the countries affected by the virus. Various government policies have been taken to prevent the spread of the virus. Government policies also have an impact on regulating the education sector in Indonesia. There was a change in the learning process, which was initially carried out face-to-face in class, then because of this pandemic there was an adjustment, namely the learning process was carried out online. The emergence of innovations from teachers also gave color to the learning process during the Covid-19 pandemic. The learning process in the field of art includes adjustments to the technical teaching and learning activities for students. The use of virtual space is a top priority during the Covid-19 pandemic for the sustainability of teaching and learning activities. This happens in the art of music, especially the vocal learning process which is carried out online. Initially, vocal practice was carried out through standing in one room offline, so now it has been adjusted, namely vocal practice learning is done through virtual. Online vocational learning is a teaching and learning activity related to technology in its implementation. Online forms of vocal learning can be done by utilizing several digital applications. Among them are using the WhatsApp application by utilizing the video call feature and sending recordings of training results by students. The use of features from WhatsApp has its respective advantages and it provides a new paradigm if both are used in the process of learning vocal practice online.
\end{abstract}

Keywords: vocal learning forms online; art education; vocal learning 


\section{Pendahuluan}

Pendidikan adalah daya atau usaha untuk bertumbuh dan berkembangnya intelektual, budi pekerti (karakter), dan tubuh anak. Ketiga usaha tersebut seharusnya secara berkesinambungan menghidupi kebutuhan anak atau peserta didik menuju kesempurnaan hidup (Ki Hadjar Dewantara, 1962). Jika dilihat dari perspektif kebudayaan, pendidikan berfungsi untuk mempertahankan, melangsungkan, dan mengembangkan eksistensinya dengan adaptasi lingkungan sekitarnya (Triyanto 2017:79). Seni merupakan sesuatu yang memuat hal-hal transendental yang belum pernah diketahui kemudian dikenal lewat sebuah karya (Sumardjo, 2000). Artinya, seni dikenal dan diketahui oleh manusia lewat perwujudan dan kreativitas penciptanya (seniman). Wujud tersebut adalah sesuatu yang dapat diindera oleh manusia lewat apa yang dipunyainya. Sebagai contoh wujud dari musik ialah suara atau bunyi, wujud dari tari ialah gerak, dan wujud dari rupa ialah garis. Ketiga wujud tersebut kemudian terbagi-bagi lagi sesuai dengan karateristik senimannya. Karya musik Bach akan berbeda dengan Mozart, tari kreasi pak Didik Thowok berbeda dengan tari kreasi lainnya, dan lukisan Affandi akan berbeda karateristiknya dengan pelukis lain. Semuanya itu dalam istilah seni disebut sebagai keberagaman bentuk ekspresi estetik dalam wujud karya seni (Triyanto 2017:88).

Kesenian di Indonesia memiliki keragaman diantaranya seni rupa, seni tari, seni drama, dan seni musik. Seni musik diantaranya mencakup permainan alat musik tiup, gesek, perkusi, dan vokal. Alat musik vokal terletak pada tubuh manusia yang berbeda dengan alat musik gesek, tiup, dan perkusi yang masing-masing memiliki alat berwujud benda mati. Seni vokal yaitu ekspresi seni seseorang dengan menggunakan teknik head voice untuk menciptakan keindahan dalam bersuara. Wujud keindahan seni vokal diantaranya disajikan dalam paduan suara dan pertunjukan solo vokal. Paduan suara yaitu penyajian komposisi vokal dengan beberapa orang penyaji dalam harmoni sopran, alto, tenor, dan bas yang dibimbing oleh conductor (satu orang yang menjadi pemimpin). Pertunjukan solo vokal yaitu seorang penyaji menyajikan komposisi vokal sesuai dengan karakter vokal dalam diri penyaji dan biasanya disajikan dalam bentuk konser.

Vokal mulai dikenal pada zaman Renaisans dengan teknik bernyanyi yang khas yaitu menggunakan suara atas dan ringan. Teknik bernyanyi mulai berkembang menyesuaikan perubahan zaman seperti pada zaman barok, klasik, dan romantik. Teknik vokal yang berkembang dan relevan sampai sekarang yaitu disebut teknik bel canto, artinya yaitu cara bernyanyi dengan memfungsikan suara atas untuk menghasilkan suara 
yang indah. Menurut Tim Musik Liturgi Yogyakarta (1992), membentuk suara dapat diperoleh melalui langkah-langkah yaitu melatih diafragma untuk bernafas, melakukan vokalisi secara teratur dan rutin setiap hari, melatih rongga dada, rongga tenggorokan, rongga mulut untuk mendapatkan suara yang bagus. Bernapas merupakan irama yang sangat alamiah dalam kehidupan manusia. Pernapasan yang teratur juga akan menciptakan suatu irama yang menenteramkan. Bernyanyi yaitu pernapasan tidak hanya memegang peranan dalam menciptakan suara, tetapi juga suasana yang dikehendaki dari suatu nyanyian. Bernyanyi merupakan suatu kecenderungan manusia untuk mengungkapkan diri, oleh karena itu bernyanyi dengan baik dapat dipelajari oleh setiap orang bahkan oleh mereka yang merasa tidak bisa.

Setiap orang mempunyai peluang untuk menguasai teknik bernyanyi yang memiliki nilai estetika tinggi. Bernyanyi dengan indah memerlukan penguasaan teknik bernyanyi secara tepat. Salah satu teknik bernyanyi yang dapat menjadi pertimbangan untuk dipelajari dan dikuasai yaitu teknik bernyanyi bel canto. Teknik tersebut memaksimalkan fungsi diafragma untuk mengirimkan napas menuju ke rongga mulut sehingga menghasilkan produksi suara yang indah. Perlu diketahui jika seseorang ingin mendapatkan hasil yang maksimal dari teknik tersebut maka disarankan untuk rajin berlatih. Adanya proses yang berkelanjutan adalah sesuatu yang menjadi prioritas dalam upaya menguasai teknik bel canto ini.

Teknik bel canto sering dikenal dengan suara seriosa yang muncul pada komposisi musik Barat dan berkembang di Indonesia. Meskipun indentik dengan gaya bernyanyi pada komposisi musik Barat, tetapi hal tersebut menjadi pendorong para komposer Indonesia untuk mengembangkan komposisi dengan orientasi penguasaan teknik bel canto. Beberapa komposer Indonesia membuat komposisi yang cocok untuk dinyanyikan menggunakan teknik bel canto, dan karya tersebut masih sering digunakan di perguruan tinggi yang memiliki fakultas musik. Setiap orang yang memiliki musikalitas dalam bernyanyi maka akan mampu menguasai teknik bel canto, tentu diperlukan disiplin berlatih dengan benar dan bersabar selama proses latihan sampai menemukan teknik bel canto. Penguasaan teknik bel canto menjadi hal baru bagi mahasiswa baru dan menjadi tantangan bagi mahasiswa lama. Dibutuhkan penyesuaian diri mahasiswa untuk menguasai teknik bel canto dalam bernyanyi. Proses adaptasi mahasiswa dalam belajar teknik bel canto diperlukan kedisiplinan berlatih, gaya belajar yang baik dan benar, kesabaran, ketelitian, dan ketekunan. Berlatih musik dapat menjadi rutinitas sehingga akan menimbulkan 
kebosanan pada mahasiswa. Salah satu indikator seseorang berhasil menguasai teknik bel canto yaitu secara fisik ketika seseorang sedang bernyanyi maka dileher tidak terlihat ototnya dalam jumlah banyak. Hal tersebut dikarenakan fungsi tenggorokan dalam teknik bernyanyi bel canto adalah sebagai jalan nafas dari diafragma menuju produksi suara atas/head voice.

Dinamika perkembangan zaman memengaruhi perilaku seseorang sebagai makhluk berbudaya. Di era revolusi industri 4.0 berdampak pada berjejalnya informasi-informasi yang bersifat cepat. Informasi dalam hal ini dapat diartikan sebagai bentuk sajian data yang mampu menjawab kebutuhan manusia yang bisa didapatkan dengan waktu yang singkat. Bagaimana strategi di bidang pendidikan seni pada era 4.0 ini memiliki keunggulan dalam menghadapi tantangan terkait teknis bagaimana seseorang mendapatkan informasi belajarnya? Kemajuan teknologi yang begitu cepat dapat menolong seseorang untuk memiliki alternatif-alternatif belajar. Sebagai contoh dalam situasi pandemi covid-19 saat ini sangat membutuhkan metode pembelajaran yang tepat sehingga proses kegiatan belajar mengajar dapat berlangsung. Diantaranya alternatif yang ada yaitu pemanfaatan ruang virtual sebagai media pembelajaran di masa pandemi covid-19.

Pemaparan di atas memberikan pengertian bahwa pemanfaatan teknologi sangat membantu dalam proses pembelajaran di masa pandemi covid-19 ini. Tulisan ini akan membahas pendidikan seni berbasis pembelajaran vokal yang dilakukan secara virtual.

\section{Pembelajaran Vokal dalam Pendidikan Seni}

Pendidikan merupakan bagian penting dalam segala aspek kehidupan masyarakat. Pendidikan berperan penting dalam mengangkat harkat dan martabat manusia, sehingga pendidikan juga menjadi salah satu ujung tombak bagi kemajuan dan perkembangan sebuah negara (Sambira \& Kristanto, 2020). Untuk itu pendidikan harus mengarah pada kebenaran objektif sebagai bentuk eksistensi pendidikan pada ilmu pengetahuan (Foucault, 2012). Pemaparan tersebut menyampaikan pesan bahwa pendidikan adalah proses belajar yang bersifat keberlanjutan.

Semangat menjadikan manusia sebagai makhluk yang mulia adalah salah satu bentuk spirit ideologi pendidikan seni. Seni hadir sebagai media di dalam dunia pendidikan yang memiliki fungsi untuk menjadikan manusia yang humanis. Sentuhan seni di dalam dunia pendidikan diharapkan mampu menumbuhkan kekuatan sensitivitas perasaan, ekspresi, kreatif, dan inovatif. Dalam pendidikan seni, fokus utamanya mengarah pada seni 
sebagai media pendidikan. Dengan kata lain, seni bukan lagi menjadi objek didik melainkan subjek didik dalam mengembangkan potensi peserta didik (Sambira \& Kristanto, 2020). Seni sebagai media di dalam pendidikan mampu membuat siswa lebih mudah menangkap pelajaran-pelajaran yang sebelumnya sulit. Diantaranya mata pelajaran sejarah, jika memanfaatkan seni sebagai media pembelajarannya maka bentuknya dapat berupa drama musikal, puisi yang di dalamnya memuat materi pelajaran sejarah sehingga siswa jadi lebih mudah mengingat dan menangkapnya karena pelajaran sejarah disampaikan lebih menarik dan kreatif.

Upaya menemukan kekuatan positif terkait pendidikan seni maka diperlukan tahapan untuk memahami arti pendidikan seni. Seperti yang dikemukakan Kristanto (2017) yaitu dalam upaya memahami makna pendidikan seni dalam istilah pendidikan seni mempunyai beberapa penafsiran maksud yaitu pendidikan mengenai seni, atau pendidikan dalam seni, atau pendidikan melalui seni. Di masyarakat muncul istilah pembanding yaitu Seni Pendidikan yang diartikan seni untuk pendidikan. Berbeda dengan pemahaman pendidikan seni yang dikemukakan oleh Harwanto (2018) yaitu pendidikan seni dapat ditinjau dari dua konsepnya yaitu pendidikan dalam seni dan pendidikan melalui seni.

Keberagaman pengertian pendidikan seni menunjukkan bahwa seni memiliki pengaruh kuat terhadap dunia pendidikan secara umum. Sedikit lembaga pendidikan yang memahami pentingnya pendidikan seni untuk menciptakan dunia pendidikan yang kreatif, inovatif, dan apresiatif. Masalah umum yaitu masih sempitnya ruang gerak seni dalam ranah pendidikan, mata pelajaran seni masih menjadi minoritas oleh para pembuat kurikulum (Kristanto, 2017).

Dalam pendidikan seni, posisi seni ada sebagai sarana pendidikan yang mengarah pada mengembangkan potensi pribadi, sosial, dan budaya. Maka dari itu, pendidikan seni harus terselenggara dan terlaksana yang berbasis pada budaya. Menurut Salam (2001) pendidikan seni berlandaskan dua pertimbangan yakni kepentingan masyarakat dan kepentingan perseorangan. Artinya pendidikan seni bertujuan memenuhi kebutuhan personal, kesadaran sosial, dan menyalurkan budaya (Chapman, 1978). Secara nasional, pendidikan seni bertujuan mengembangkan daya kesadaran dan kepekaan estetik (apresiasi), daya cipta (kreativitas), dan memberi kesempatan berekpresi. Pendidikan seni musik bertujuan untuk memberi kesempatan kepada peserta didik untuk berekspresi, berapresiasi, berkreasi membentuk harmoni, dan menciptakan keindahan melihat kondisi yang ada di sekitarnya (Chrisnahanungkara, 2020). Secara umum, anak atau peserta didik 
didorong untuk mengekspresikan gagasan-gagasan secara bebas. Adapun tiga tujuan pendidikan seni di sekolah berupa apresiatif, kreatif, dan ekspresif menjadi kesatuan dalam membentuk kepribadian yang sadar akan nilai-nilai sosial dan budaya (Triyanto, 2017). Fungsi pendidikan seni mengarah pada dua hal yakni media pendidikan estetik dan media pendidikan kreatif. Untuk itu dapat dikatakan fungsi pendidikan seni bersifat ganda, karena pendidikan seni juga menjadi media pelestarian dan pewarisan nilai-nilai sosial budaya, yang di dalamnya terkandung dimensi kognitif dan afektif.

Seni dalam konteks pendidikan formal memiliki peran penting demi kemajuan budaya bangsa. Seni juga hadir di pendidikan non-formal dan informal yang dapat berperan untuk menjaga keseimbangan arus dinamika zaman yang masing-masing zaman membawa dampak terhadap budaya bangsa. Di era revolusi industri 4.0 membawa dampak pada generasi yang ada dan berdampak juga pada kebudayaan bangsa. Era revolusi industri 4.0 memiliki pengaruh positif pada bangsa ini yaitu kemajuan teknologi yang begitu cepat dan pesat mampu meningkatkan efektivitas dan efisiensi di dalam bidang tertentu.

Menurut Mark K. Smith dkk (2009), ada tiga dasar dalam teori pembelajaran yaitu behaviorisme, kognitivisme, dan konstruktivisme. Behaviorisme yaitu berdasarkan pada perubahan-perubahan perilaku yang dapat diamati. Behaviorisme memfokuskan diri pada sebuah pola perilaku baru yang diulangi sampai ia menjadi otomatis. Kognitivisme yaitu berdasarkan pada proses pemikiran di balik perilaku. Perubahan-perubahan dalam perilaku diamati, dan digunakan sebagai indikator dalam kaitannya dengan apa yang terjadi di dalam pikiran pembelajar. Konstruktivisme yaitu berdasarkan pada premis bahwa kita semua mengonstruksi perspektif kita sendiri terhadap dunia, melalui pengalaman individu dan skema.

Pembelajaran merupakan kegiatan terarah yang melibatkan guru dan murid dalam setiap proses perkembangannya. Kegiatan terarah tersebut dapat melibatkan berbagai aspek di dalamnya. Dalam pembelajaran terdapat suatu perencanaan, pelaksanaan, evaluasi, dan keberlanjutan. Model pembelajaran sangat beragam bentuknya dan masing-masing memiliki keunikan. Berikut ini adalah contoh model pembelajaran yang mengusung pendekatan pendidikan damai terhadap proses pembelajaran yang dilakukan. Sebagai contoh Misye Pattipeilohi (2015) dalam penelitiannya yang berjudul Pendidikan damai dalam pembelajaran vokal berbasis pendidikan karakter pada paduan suara Sunadesis di Maluku. Penelitian tersebut mengkaji pendidikan damai melalui metode hukuman dan hadiah dan metode outbound menjadi salah satu solusi dalam pembelajaran vokal paduan 
suara Sunadesis untuk menghindari pendisiplinan yang keras serta mendidik karakter individual paduan suara. Selain itu, metode hukuman dan outbound digunakan juga untuk membentuk teknik vokal dan mendidik karakter individual. Melalui proses pembelajaran dengan menggunakan metode dalam pendidikan damai maka ada nilai-nilai pendidikan secara universal yang diperoleh yaitu nilai agama, nilai budaya, nilai moral, dan nilai estetika.

Unsur-unsur yang terdapat dalam proses pembelajaran vokal antara lain estetika atau keindahan, praktikum studio, sejarah seni, tinjauan/kritik seni. Unsur estetika dalam vokal yaitu seseorang bernyanyi hanya asal bunyi dan bernyanyi dengan indah berdasarkan teknik vokal yang benar tentu menghasilkan produksi suara yang berbeda. Diantaranya, dalam sebuah pertunjukan maka penonton dapat terkagum atas suara yang indah sehingga memicu minatnya untuk belajar vokal. Unsur praktikum studio dalam vokal yaitu setiap siswa memiliki gaya yang berbeda dalam berlatih vokal menurut teori membentuk suara yang sudah diajarkan oleh gurunya. Hal tersebut membuktikan bahwa siswa memiliki kreasi dan ekspresi dalam berlatih vokal demi mendapatkan hasil yang baik. Unsur sejarah seni dalam vokal yaitu siswa mendapat pengalaman mempelajari karya komposer dari beragam zaman menurut periodisasinya. Hal tersebut adalah sebagai pengalaman kultur kepada siswa atas setiap karya yang dipelajari dan disajikan. Unsur tinjauan/kritik seni dalam vokal yaitu dalam setiap pertunjukan yang disajikan ternyata setiap siswa memiliki keunikan apresiasi setiap karya yang disajikan. Dan hal itu menunjukkan bahwa siswa memiliki pengalaman apresiasi karya seni yang dipelajari sehingga muncul kekhasan.

\section{Integrasi Teknologi dalam Pembelajaran Vokal}

Sekarang ini, dunia telah memasuki era revolusi industri generasi 4.0 yang ditandai dengan meningkatnya konektivitas, interaksi serta perkembangan sistem digital, kecerdasan artifisial, dan virtual. Dengan semakin konvergennya batas antara manusia, mesin dan sumber daya lainnya, teknologi informasi dan komunikasi tentu berimbas pula pada berbagai sektor kehidupan. Salah satunya yakni berdampak terhadap sistem pendidikan di Indonesia (lihat Lase, 2019). Sistem pendidikan di Indonesia pada periode waktu sepuluh tahun yang lalu telah menempatkan teknologi sebagai alternatif media dalam pendidikan, tetapi mengetahui perubahan zaman pada saat ini maka teknologi menjadi kebutuhan pokok dalam dunia pendidikan. Hal tersebut dapat terwujud melalui pengelolaan administrasi pendidikan, metode pembelajaran, media pembelajaran, 
penyusunan materi-materi belajar, dan promosi bidang pendidikan. Terlebih untuk kepentingan promosi pendidikan upaya mendapatkan peserta didik dalam jumlah banyak maka teknologi dapat menjadi pertimbangan utama dalam ranah promosi.

Dalam kurun waktu sepuluh tahun lalu, masih ada jarak yang jauh antara aktivitas pendidikan dengan pemanfaatan teknologi. Namun saat ini hal tersebut terjadi pergeseran, teknologi dapat menjadi kebutuhan primer dalam dunia pendidikan. Realisasinya dapat dalam bentuk munculnya aplikasi-aplikasi yang berorientasi pada dunia pendidikan. Aplikasi tersebut mendukung secara holistik kegiatan belajar mengajar pada ranah pendidikan. Melihat fenomena saat ini, proses edukasi menggunakan teknologi menjadi kebutuhan utama bagi guru dan murid. Pembelajaran yang dilakukan secara virtual mengantarkan orang-orang yang terlibat dalam dunia pendidikan saat ini ke dalam dunia pendidikan berbasis online. Pendidikan berbasis online saat ini adalah sebuah fenomena adanya integrasi antara teknologi dan pendidikan.

Integrasi teknologi dalam pembelajaran vokal melalui daring menjadi bagian dalam pembahasan ini. Pembelajaran vokal melalui daring sudah pasti memerlukan teknologi di dalam teknis pelaksanaannya. Upaya kreatif diantaranya yaitu memanfaatkan aplikasiaplikasi yang memiliki fitur audio video di dalamnya. Teknis pelaksanaan proses belajar vokal secara daring diantaranya dapat dilakukan melalui aplikasi whatsapp dengan video call secara langsung dalam waktu bersamaan antara guru dan murid. Dalam proses itu terjadi interaksi antara guru dan murid dan proses pembimbingan belajar vokal dapat dilakukan. Jenis metode tersebut dapat disebut sebagai pembelajaran dua arah yaitu guru dan murid dapat berproses dalam waktu yang sama. Di sisi lain, terdapat juga metode pembelajaran satu arah. Misalnya seorang murid memberikan hasil rekaman audio-visual kepada gurunya untuk mendapat koreksi. Metode tersebut disebut sebagai pembelajaran satu arah karena proses belajar terjadi pada waktu yang tidak bersamaan dan tidak ada interaksi sosial di dalamnya.

Selanjutnya contoh bentuk pembelajaran vokal secara daring dapat dilakukan melalui aplikasi zoom. Ketika bentuk pembelajaran vokal secara daring dilakukan melalui aplikasi zoom, beberapa hal yang perlu dipertimbangkan yaitu ketersediaan kuota internet, aplikasi zoom dapat diakses melalui laptop dan handphone. Jika akses menggunakan handphone, maka perlu disiapkan alat penyangganya supaya pembelajaran vokal dapat berlangsung secara maksimal. Hal tersebut dapat dipersiapkan oleh pengajar dan murid vokal karena memiliki kebutuhan yang sama sebagai upaya untuk optimalisasi proses 
pembelajaran vokal secara daring. Ketersediaan akses internet yang kuat juga perlu dipikirkan karena jika ternyata jaringan internet lemah maka hal itu dapat mengganggu proses pembelajaran. Letak perbedaan yang signifikan ketika membandingkan pembelajaran secara offline dengan pembelajaran secara daring yaitu durasi proses pembelajaran vokal secara daring berpotensi tidak tepat waktu karena beberapa kendala teknis. Keunggulan pembelajaran vokal secara daring yaitu berorientasi pada banyaknya jumlah pertemuan. Hal ini diartikan dapat bersemuka secara daring maupun memberikan hasil rekaman berlatih dari peserta didik kepada gurunya. Peserta didik lebih leluasa untuk memperhatikan secara kuantitas proses pembimbingan dengan gurunya.

Masing-masing metode memiliki keunggulan yaitu jika memilih metode pembelajaran satu arah maka kualitas audio ataupun visual lebih tinggi karena berpeluang untuk proses editing dan tidak bergantung pada kekuatan sinyal internet. Koreksi dari guru dapat lebih lengkap karena kecenderungan memiliki waktu yang lebih lama untuk menganalisis hasil belajar muridnya melalui rekaman audio visual. Keunggulan metode pembelajaran dua arah melalui daring yaitu terjadinya interaksi dalam waktu yang bersamaan sehingga murid dan guru dapat lebih jelas mengetahui perkembangan teknik vokal yang dialami oleh murid. Tetapi metode ini memiliki kekurangan yaitu kelancaran proses pembelajaran bergantung pada kekuatan sinyal internet yang stabil. Adapun strategi yang dapat dipakai yaitu dari dua metode tersebut dapat digabungkan sehingga semakin lengkap untuk mendukung optimalisasi proses pembelajaran vokal secara virtual atau daring.

\section{Kesimpulan}

Proses pendidikan yang sebelumnya sangat mendominasi yaitu dilakukan secara luar jaringan, maka dalam situasi pandemi covid-19 ini proses pendidikan beralih ke dalam jaringan dan secara familiar disebut pembelajaran dalam jaringan. Hal tersebut berdampak pada berbagai bidang keilmuan pendidikan, diantaranya keilmuan bidang seni. Situasi pandemi covid-19 ini memunculkan penyesuaian-penyesuaian di bidang seni musik, seni tari, dan seni rupa. Masing-masing bidang seni memikirkan langkah ideal dalam bingkai virtual pada pembelajarannya. Kaitannya dengan seni musik khususnya pembelajaran vokal, maka situasi pandemi covid-19 ini memunculkan ide-ide kreatif supaya pembelajaran tetap berlangsung dengan efektif. Salah satu bentuk pembelajaran vokal di masa pandemi covid-19 ini adalah pembelajaran vokal melalui ruang virtual atau dalam 
jaringan yang memanfaatkan teknologi. Paradigma baru untuk metode pembelajaran di masa depan meskipun pandemi covid-19 sudah selesai yaitu penggunaan teknologi sangat penting untuk diterapkan dalam pembelajaran yang dilakukan secara offline serta ruang virtual perlu dibudayakan.

\section{Kepustakaan}

Chapman, L. (1978). Approach to Art Education. New York: Harcout Brace Jovanovich.

Chrisnahanungkara, A. J. (2020). Pendidikan Seni Musik Berbasis Bahan Ajar Multikultural. Tonika: Jurnal Penelitian Dan Pengkajian Seni, 3(1), 39-50. https://doi.org/10.37368/tonika.v3i1.132

Foucault, M. (2012). Arkeologi Pengetahuan (Terj. Inyiak Ridwan Muzir). Yogyakarta: Ircisod.

Harwanto, Dody Candra. (2018). MEMAKNAI INKULTURASI DALAM PENDIDIKAN SENI DAN KONSERVASI. Tonika: Jurnal Penelitian Dan Pengkajian Seni, 1(1), 40-50. https://doi.org/10.37368/tonika.v1i1.10

Kristanto, A. (2017). Memahami Paradigma Pendidikan Seni. Jurnal Abdiel: Khazanah Pemikiran Teologi, Pendidikan Agama Kristen, Dan Musik Gereja, 1(1), 119-126. https://doi.org/10.37368/ja.v1i01.90

Lase, D. (2019). Pendidikan di Era Revolusi Industri 4.0. SUNDERMANN Jurnal Ilmiah Teologi Pendidikan Sains Humaniora Dan Kebudayaan, 1(1), 28-43. https://doi.org/10.36588/sundermann.v1i1.18

Salam, S. (2001). Pendidikan Seni Rupa di Sekolah Dasar. Makassar: Universitas Negeri Makassar.

Sambira, Z., \& Kristanto, A. (2020). Paradigma Pendidikan Seni Berbasis Karakter Dalam Musik Ma'Badong. Tonika: Jurnal Penelitian Dan Pengkajian Seni, 3(1), 15-26. https://doi.org/10.37368/tonika.v3i1.128

Sumardjo, J. (2000). Filsafat Seni. Bandung: ITB Bandung.

Triyanto. (2017). Spirit Ideologis Pendidikan Seni. Semarang: Cipta Prima Nusantara. 